\title{
ANTIBACTERIAL ACTIVITY OF AKAR KUNING (ARCANGELISIA FLAVA) SECONDARY METABOLITES: MOLECULAR DOCKING APPROACH
}

\author{
MOHAMMAD RIZKI FADHIL PRATAMA ${ }^{*}{ }^{*}$, SURATNO ${ }^{2}{ }^{\text {, EVI MULYANI }}{ }^{1}$ \\ ${ }^{1}$ Department of Pharmacy, Faculty of Health Sciences, Universitas Muhammadiyah Palangkaraya, Palangka Raya, Central Kalimantan \\ 73111, Indonesia. ${ }^{2}$ Department of Medical Laboratory Technology, Faculty of Health Sciences, Universitas Muhammadiyah Palangkaraya, \\ Palangka Raya, Central Kalimantan 73111, Indonesia. Email: m.rizkifadhil@umpalangkaraya.ac.id
}

Received: 18 September 2018, Revised and Accepted: 01 October 2018

ABSTRACT

Objectives: Akar kuning (Arcangelisia flava) was known to have various pharmacological activities including as antibacterial. Several Gram-positive and Gram-negative bacteria show response to akar kuning secondary metabolites, although the type of metabolites that inhibit the growth of each type of bacteria not yet known. This study aims to obtain the prediction of metabolites from akar kuning with the greatest antibacterial potential against various types of antibacterial receptors.

Methods: Molecular docking was performed using Autodock Vina 1.1.2 on several secondary metabolites of akar kuning against active site of several antibacterial receptors that were known for many antibiotics including as cell wall, protein, nucleic acid synthesis inhibitors, and antimetabolites. The main parameter used was the free energy of binding as affinity marker.

Results: The docking results show that among 11 metabolites studied, 6-hydroxyfibraurin, berberine, and fibleucin provided the lowest free energy of binding between 11 antibacterial receptors compared with natural substrates or inhibitors from each receptor. Interesting results show by berberine as inhibitor of protein synthesis with possibility of allosteric site discovery. Berberine also shows more than $75 \%$ similarity with natural substrate of cell wall inhibition receptor, indicating possible similar type of interaction.

Conclusion: Overall, it seems that for the selected secondary metabolites of akar kuning, the main mechanism of action was the inhibition of protein and cell wall synthesis, which was shown by berberine.

Keywords: Akar kuning, Antibacterial, Arcangelisia flava, Berberine, Cell wall synthesis.

(C) 2018 The Authors. Published by Innovare Academic Sciences Pvt Ltd. This is an open access article under the CC BY license (http://creativecommons. org/licenses/by/4. 0/) DOI: http://dx.doi.org/10.22159/ajpcr.2018.v11i11.29189

\section{INTRODUCTION}

The discovery of new antimicrobial compounds is undeniably still one of the interesting topics to be studied, where the need for new antimicrobials to combat microbial resistance is still constrained by the availability of antimicrobials that are safe to use $[1,2]$. Our backwardness from the process of microbial resistance several times puts us in a dangerous position with the spread of infection due to harmful microbes, as has happened in the case of avian and swine influenza that once threatened humanity in the early 2000s $[3,4]$. Lucky for us, nature always gives clues on how to win the fight with these microbial infections. Various compounds obtained from natural products, both direct and modified extraction, have been proven to overcome the problem of microbial resistance $[5,6]$.

Although there is a tendency to shift the approach to the discovery of new antimicrobial compounds with a rational approach using computer-aided drug design, the discovery of compounds derived from natural products remains an interesting field to do considering the large selection of medicinal plants that have not been studied $[7,8]$. While the rational approach provides ideas for optimizing the antimicrobial activity of these compounds, tracing active compounds from natural products provide a new dimension for starting compounds that can be optimized by rational approaches $[9,10]$. The combination of both approaches provides comprehensive information for researchers to be able to develop active metabolite derivatives from medicinal plants [11]. However, both approaches share similar problems where not all medicinal plants that have antimicrobial activity are produced by a single compound, making it difficult to analyze them in silico because rational approaches require interaction between single ligand receptors [12]. In silico analysis of secondary metabolites one by one is a way that can be done to prove the efficacy of each metabolite [13].

One of the plants known to be efficacious as an antimicrobial but not yet known as the secondary metabolite responsible for this activity is the akar kuning (Arcangelisia flava). Several studies have shown that the ethanol extract of akar kuning stems has excellent antimicrobial activity against various microbes both bacteria and fungi $[14,15]$. The antimicrobial spectrum of akar kuning extracts is even quite extensive including some Gram-positive and Gramnegative bacteria [16,17]. This activity is mainly associated with the ability of secondary root metabolites as antimicrobials through various pathways including inhibition of cell wall, protein, nucleic acid synthesis, and antimetabolites [18-20]. Still, the type of secondary metabolite that has the most potent activity and the mechanism of antimicrobial activity that occurs from akar kuning is still unknown.

This study aims to find secondary metabolites of akar kuning with the highest potential as antimicrobials, as well as determining the types of antimicrobial mechanisms that occur in these metabolites. The study was conducted in silico by molecular docking method to determine secondary metabolites with the highest affinity for several known antimicrobial receptors. Metabolites with the highest affinity then compared with comparative compounds to determine the level of similarity of amino acid interactions that occur, indicating this potential as an antimicrobial compound. 


\section{METHODS}

\section{Ligands preparation}

The ligand used was 11 known secondary metabolites from akar kuning as shown in Fig. 1 consisting of 2-dehydroaxyarcangelisinol (1), 6-hydroxyarcangelisin (2), 6-hydroxyfibleucin (3), 6-hydroxyfibraurin (4), berberine (5), columbamine (6), fibleucin (7), fibraurin (8), jatrorrhizine (9), palmatine (10), and tinophyllol (11) [11,15]. The two-dimension structure of ligands was sketched using Gauss View 3.08 Software from Gaussian, Inc. All structures were geometry optimized by Hartree-Fock method basis set 3-21G with Gaussian $03 \mathrm{~W}$ software from Gaussian, Inc. Ideal conformation of following compounds has been provided by performing geometry optimization, which approaching conformation of these compounds in nature [9]. Optimized structures format changed from.log to.pdb using Open Babel 2.4.1 software [21]. The using of Open Babel software makes it very easy to transform ligands from one format to another [22]. Docking program used in this study was Autodock Vina 1.1.2 from The Scripps Research Institute [23]. All ligands then are given the charge and set torque using software AutoDockTools 1.5.6 [24].

\section{Receptors preparation}

The molecular structure of all receptors was obtained from website of Protein Data Bank (PDB) http://www.rscb.org. The receptors were downloaded in.pdb format and then removed the unused portion, added the non-polar hydrogen group, given the charge, and set the grid box size and coordinate using software AutoDockTools 1.5.6 [25]. 11 receptors were used in the docking process and were divided into four groups consisting of cell wall, protein, and nucleic acid synthesis inhibitors, as well as antimetabolites [18-20]. The used structure of each receptor is the active site which is known as antimicrobial as cocrystal ligands.

\section{Molecular docking}

Molecular docking is done using software AutoDock Vina 1.1.2 from The Scripps Research Institute. The main parameter used in docking process was the free energy of binding $(\Delta G)$ as affinity marker and amino acid's residues as similarity marker $[7,26]$. The more negative $\Delta G$ shows the higher ligand affinity for the active side of the receptor [27]. Test ligand with the highest affinity was compared with redocking result of cocrystal ligand to determine the potency of test ligand as each receptors inhibitor by comparing the value of $\Delta G$ [28]. The amino acid's residues of selected test ligand for each receptor then compared with amino acid's residues of cocrystal ligand to assess the similarity of interaction between test and cocrystal ligand. The more similar amino acid's residues indicate a higher probability that the test ligand will have similar activity with the cocrystal ligand [9]

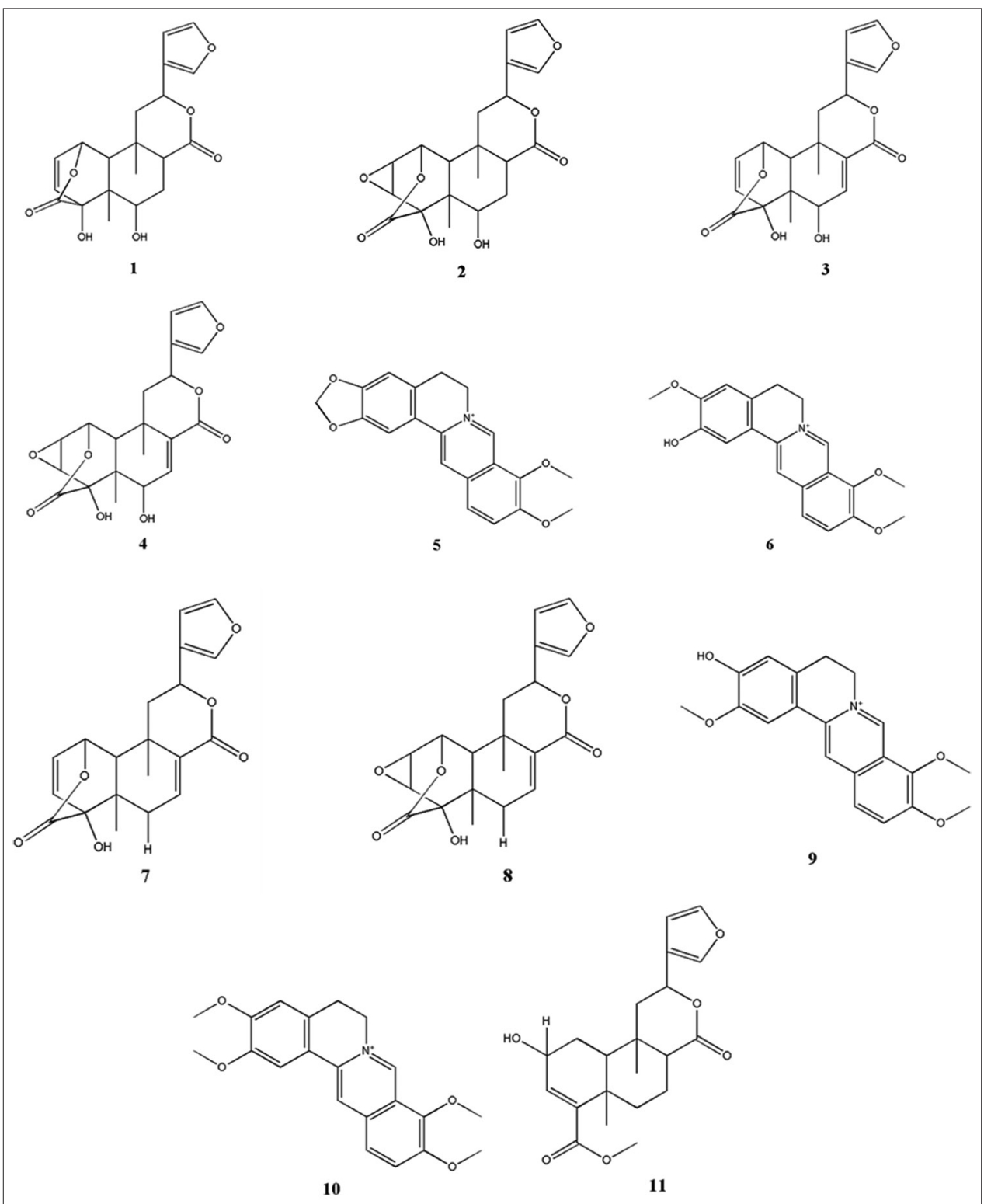

Fig. 1: Structure of known secondary metabolites from akar kuning subjected for docking studies against antibacterial target proteins 


\section{RESULTS AND DISCUSSION}

Docking results were performed on the entire surface of each receptor with energy range, exhaustiveness, and number of modes parameters score 3, 8 , and 9, respectively. This number is default parameter for Autodock Vina 1.1.2 for molecular docking purpose. Higher parameter will increase the accuracy of docking results [22]. The docking results data of all test ligands to all receptors were compared each other as shown in Table 1.

The first interesting thing to note is that all ligands give a negative $\Delta \mathrm{G}$ value to all receptors, in other words, all ligands have an affinity for the active side of each receptor. The interaction that occurs between all ligands of each receptor will take place spontaneously, which is not always the case $[27,29]$. The first conclusion that can be drawn is that all test ligands used have the potential to interact with antimicrobial receptors, which means that they have the potential to be developed as antimicrobial compounds. However, not all ligands have a very negative $\Delta \mathrm{G}$ value; hence, comparison with cocrystal ligands must be done to assess the real affinity of each test ligand [30]. As shown in Table 1, there are only three test ligands at eight receptors which show a more negative $\Delta \mathrm{G}$ value than cocrystal ligand, where four of them are shown by berberine, an isoquinoline derivative alkaloid found in akar kuning and several other medicinal plants. At first glance, ligands that show the highest affinity compared to comparative ligands are berberine at protein synthesis receptors (PDB ID 4WYC) which shows a difference of $\Delta \mathrm{G}$ of $2.7 \mathrm{kcal} / \mathrm{mol}$. However, aspects that must be considered in molecular docking not only affinity, but also the similarity of amino acid residues [31].

Amino acid residues are another important parameter that must be considered, especially because of the high degree of uncertainty in molecular docking [24]. No matter, how large the $\Delta G$ difference between the test and comparative ligand docking results, if the amino acids that interact with the test ligand differ greatly from the comparative ligand, it is likely that the interaction will also be different [32]. Hence, it is wise to consider how the degree of similarity between amino acid residues from test ligands and comparative ligands to determine ligands with the highest affinity [33]. A comparison between amino acid residues from docking results of test and cocrystal ligand for each receptor is shown in Table 2.

In fact, the amino acid residue shown by berberine at the 4WYC receptor is completely different from that shown by cocrystal ligands, as shown in Fig. 2. These results imply that most likely the interaction between berberine and 4WYC receptors will be different from comparative ligands. However, different types of interactions do not mean that berberine does not have antimicrobial activity as an inhibitor of protein synthesis. Recent studies even shown that berberine can inhibit protein synthesis in microbes in vitro $[34,35]$. The different types of interactions found actually show that berberine is able to bind to the active site which is different from that shown by cocrystal ligand, perhaps even as an allosteric site. Interestingly, this also occurs in other protein synthesis inhibitors receptor (PDB ID 1HNJ) where none of the berberine amino acid residues are similar to comparative ligands. This certainly provides an advantage because the discovery of the allosteric site of the antimicrobial receptor can overcome the problem of antimicrobial resistance in microbes [6].

Another interesting feature is shown by berberine against cell wall synthesis receptor inhibitors (PDB ID 2ZDQ a D-Alanine:D-Alanine Ligase enzyme), where three of the four amino acid residues in the cocrystal ligand also interact with berberine. This shows that berberine interactions are almost similar to those given by the natural substrate of the 2ZDQ receptor, in this case adenosine triphosphate (ATP) [18]. Visual observations as shown in Fig. 3 confirm that the position of berberine bonds is identical to the structure of adenosine in ATP so that parts with similar bonding positions are not functional elements of ATP phosphate groups. This assertion is important because the binding portion of ATP is an adenosine group so that if the interaction occurs in the phosphate group, then the possibility of the interaction occurring will not be the similar [36]. Similar interactions show that berberine can bind to receptors and become a competitive inhibitor of ATP. This is very beneficial because the ZZDQ receptor is a ligase enzyme that requires ATP as a phosphate source [37]. Berberines that do not have a phosphate group and can compete with ATP to bind to the active side of the receptor can cause the microbial cell wall catalysis process to stop and eventually kill the microbes $[38,39]$.

\section{CONCLUSION}

This study was successfully found the secondary metabolites of akar kuning with the highest potential as antimicrobials with berberine show affinity as inhibitors of protein and cell wall synthesis. Another valuable information that is obtained is the possibility of an allosteric site of the protein synthesis receptor, as demonstrated by berberine with very high affinity. Further, exploration of the allosteric site can be used to find antimicrobial compounds with higher activity as protein synthesis inhibitors, both from berberine derivatives and other compounds. Thus, with the introduction of metabolites with the highest antimicrobial activity, the use of akar kuning as antimicrobials can be optimized by extracting berberine as much as possible with the appropriate method.

\section{ACKNOWLEDGMENT}

This work was supported by a grant from Directorate of Research and Community Service, Ministry of Research, Technology and Higher Education Republic of Indonesia through the scheme Penelitian Dosen Pemula with grant number $3 / \mathrm{E} / \mathrm{KPT} / 2018$.

\section{AUTHORS' CONTRIBUTIONS}

All authors took part in the conduction of the study. Concept and study design were done by all authors. Mr. MRF Pratama conducted the simulations and data interpretation.

\section{CONFLICTS OF INTEREST}

All authors declare that they have no conflicts of interest in this study.

Table 1: Docking results from metabolites of akar kuning toward antimicrobial receptors

\begin{tabular}{|c|c|c|c|c|c|c|c|c|c|c|c|c|c|}
\hline \multirow{3}{*}{$\begin{array}{l}\text { Receptor } \\
\text { Type of receptors } \\
\text { Inhibition of cell wall synthesis }\end{array}$} & \multicolumn{2}{|c|}{ Validation } & \multicolumn{11}{|c|}{$\Delta G$ of ligand $(\mathrm{kcal} / \mathrm{mol})$} \\
\hline & PDB ID & $\Delta \mathrm{G}(\mathrm{kcal} / \mathrm{mol})$ & 1 & 2 & 3 & 4 & 5 & 6 & 7 & 8 & 9 & 10 & 11 \\
\hline & 1UAG & -9.1 & -8.6 & -8.4 & -8.1 & -8.5 & -7.9 & -7.9 & -7.9 & -8.6 & -7.8 & -7.9 & -8.1 \\
\hline & $2 \times 50$ & -8.4 & -8.6 & -8.7 & -8.4 & -7.9 & -6.9 & -7.0 & -8.9 & -8.2 & -7.1 & -6.7 & -7.7 \\
\hline & 2ZDQ & -8.8 & -7.6 & -7.1 & -7.1 & -7.2 & -9.6 & -6.6 & -7.3 & -7.3 & -6.5 & -6.7 & -6.1 \\
\hline & 3UDI & -7.2 & -8.0 & -8.0 & -8.9 & -9.1 & -8.1 & -7.5 & -8.9 & -8.6 & -7.5 & -7.4 & -7.8 \\
\hline \multirow[t]{2}{*}{ Inhibition of protein synthesis } & $1 \mathrm{HNJ}$ & -6.5 & -7.6 & -7.7 & -6.8 & -7.4 & -8.2 & -7.9 & -6.9 & -7.3 & -7.5 & -7.4 & -6.3 \\
\hline & 4WYC & -7.2 & -9.5 & -9.5 & -9.1 & -9.3 & -9.9 & -9.1 & -9.2 & -9.6 & -8.9 & -9.1 & -8.2 \\
\hline \multirow{2}{*}{$\begin{array}{l}\text { Inhibition of nucleic acid } \\
\text { synthesis }\end{array}$} & $1 \mathrm{KZN}$ & -8.7 & -7.4 & -6.8 & -7.3 & -8.1 & -8.0 & -7.6 & -7.6 & -7.8 & -7.4 & -7.4 & -6.7 \\
\hline & 3TTZ & -7.8 & -7.1 & -7.7 & -7.2 & -8.1 & -7.5 & -7.4 & -6.8 & -7.1 & -7.6 & -7.3 & -6.8 \\
\hline \multirow[t]{3}{*}{ Antimetabolites } & 2VEG & -7.1 & -7.6 & -7.7 & -6.9 & -7.9 & -7.6 & -7.4 & -7.1 & -7.5 & -7.0 & -7.3 & -7.1 \\
\hline & 3SRW & -8.9 & -6.8 & -6.8 & -6.6 & -7.4 & -9.1 & -9.0 & -7.1 & -7.2 & -9.0 & -8.7 & -6.0 \\
\hline & 3TYE & -9.9 & -7.9 & -8.1 & -7.8 & -7.9 & -7.9 & -7.7 & -7.8 & -7.7 & -7.5 & -7.5 & -6.8 \\
\hline
\end{tabular}

Bold numbers indicate ligands with higher affinity than cocrystal ligands. PDB: Protein data bank 


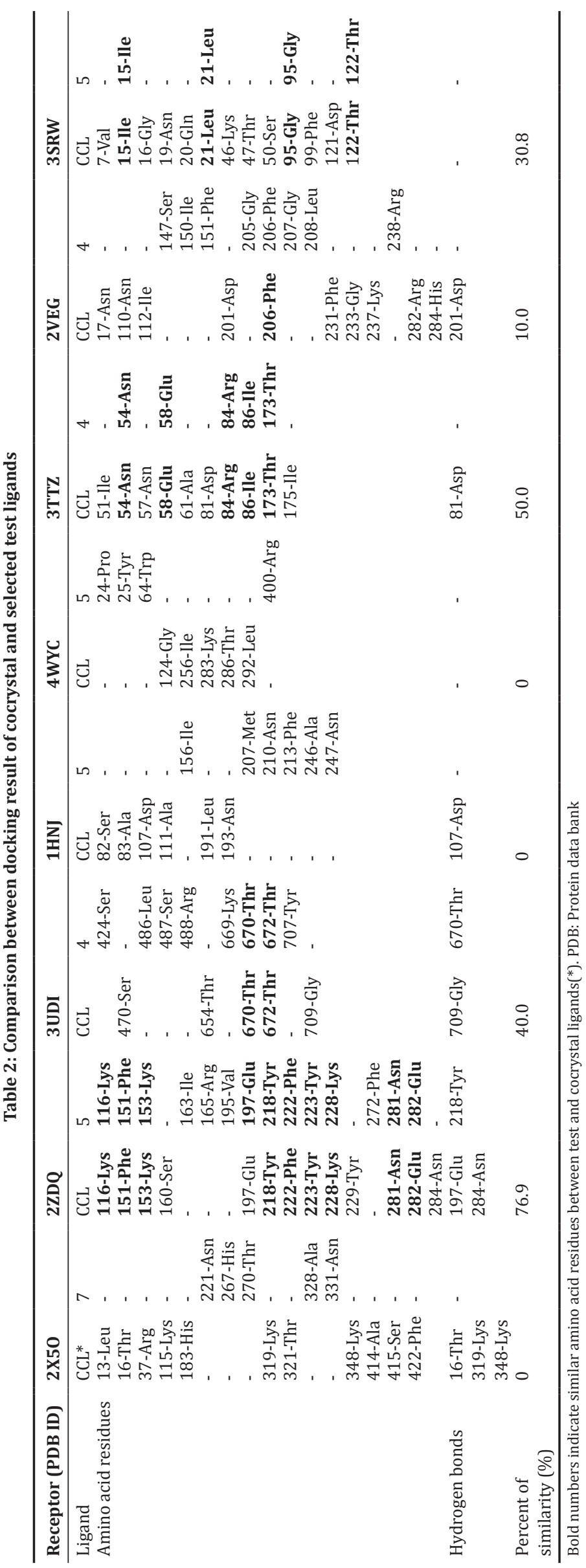




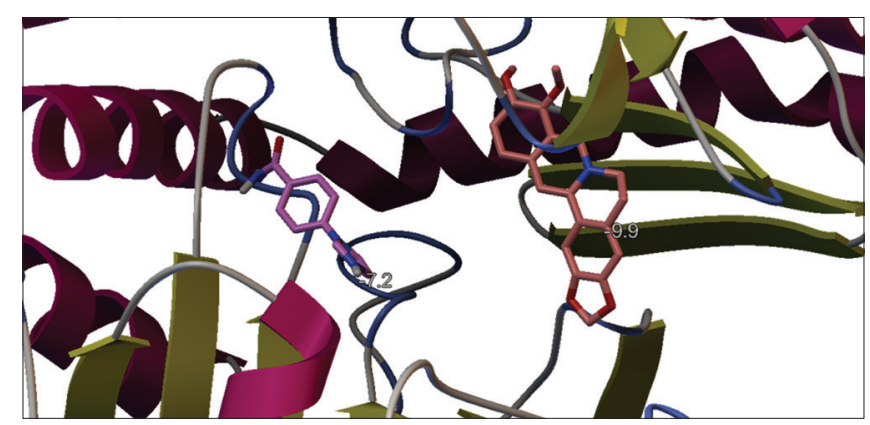

Fig. 2: Comparison of cocrystal ligand (magenta) of 4WYC with berberine (peach) position

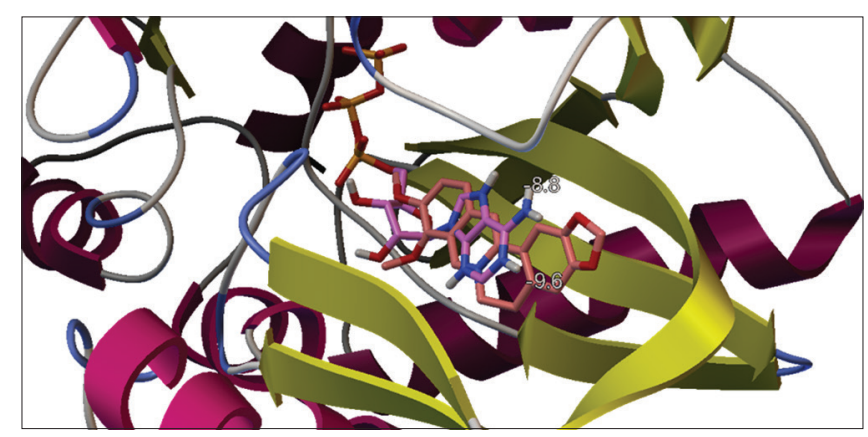

Fig. 3: Comparison of cocrystal ligand (magenta) of 2ZDQ with berberine (peach) position

\section{REFERENCES}

1. Gomes ES, Schuch V, Lemos EG. Biotechnology of polyketides: New breath of life for the novel antibiotic genetic pathways discovery through metagenomics. Braz J Microbiol 2013;44:1007-34.

2. Kong C, Eng S, Lim M, Nathan S. Beyond traditional antimicrobials: A Caenorhabditis elegans model for discovery of novel anti-infectives. Front Microbiol 2016;7:1956.

3. Ma W, Kahn RE, Richt JA. The pig as a mixing vessel for influenza viruses: Human and veterinary implications. J Mol Genet Med 2009;3:158-66.

4. Smith JR. Oseltamivir in human avian influenza infection. J Antimicrob Chemother 2010;65 Suppl 2:ii25-33.

5. Yap PS, Yiap BC, Ping HC, Lim SH. Essential oils, a new horizon in combating bacterial antibiotic resistance. Open Microbiol J 2014;8:6-14.

6. Munita JM, Arias CA. Mechanisms of antibiotic resistance. Microbiol Spectr 2016;4:10.

7. Pratama MR, Gusdinar T. Between artemisinin and derivatives with neuraminidase: A docking study insight. Asian J Pharm Clin Res 2017;10:304-8.

8. Atanasov AG, Waltenberger B, Pferschy-Wenzig E, Linder T, Wawrosch C, Uhrin P, et al. Discovery and resupply of pharmacologically active plant-derived natural products: A review. Biotechnol Adv 2015;33:1582-614

9. Pratama MR, Sutomo S. Chemical structure optimization of lupeol as ER-A and HER2 inhibitor. Asian J Pharm Clin Res 2018;11:298-303.

10. Cragg GM, Newman DJ. Natural products: A continuing source of novel drug leads. Biochim Biophys Acta 2013;1830:3670-95.

11. Pratama MR. Akar kuning (Arcangelisia flava) as neuraminidase inhibitor: Molecular docking and pharmacophore optimization approach. Adv Health Sci Res 2017;6:502-11.

12. Ginovyan M, Petrosyan M, Trchounian A. Antimicrobial activity of some plant materials used in Armenian traditional medicine. BMC Complement Altern Med 2017; 17:50.

13. Yi F, Li L, Xu L, Meng H, Dong Y, Liu H, et al. In silico approach in reveal traditional medicine plants pharmacological material basis. Chin Med 2018:13:33.

14. Setyowati R, Sudarsono S, Setyowati EP. The effect of water soluble stem extract kayu kuning (Arcangelisia flava L Merr) on the growth inhibition of Candida albicans ATCC 10231 and Trichophyton mentagrophytes in vitro. Biol Med Natl Prod Chem 2014;3:15-9.
15. Pratama MR. Akar kuning (Arcangelisia flava) as EGFR inhibitor: In silico study. J Farmagazine 2016;3:6-16.

16. Rosita M, Monalisa SS, Rozik M. In vitro test of natural antibacterial activity of yellow-fruit moonseed Arcangelisia flava Merr. Leaf on bacterium Pseudomonas fluorescens under different doses. AACL Bioflux 2018;11:288-94.

17. Heryani H, Nugroho A. Study of yellow root (Arcangelisia flava Merr) as a natural food additive with antimicrobial and acidity-stabilizing effects in the production process of palm sugar. Procedia Environ Sci 2015;23:346-50

18. Alves MJ, Froufe HJ, Costa AF, Santos AF, Oliveira LG, Osorio SR, et al. Docking studies in target proteins involved in antibacterial action mechanisms: Extending the knowledge on standard antibiotics to antimicrobial mushroom compounds. Molecules 2014;19:1672-84.

19. Dharani RS, Ranjitha R, Sripathi R, Muhammad KS, Ravi S. Docking studies in target proteins involved in antibacterial action mechanisms: Alkaloids isolated from Scutellaria genus. Asian J Pharm Clin Res 2016;9:121-5

20. Cheng K, Zheng QZ, Qian Y, Shi L, Zhao J, Zhu HL, et al. Synthesis, antibacterial activities and molecular docking studies of peptide and schiff bases as targeted antibiotics. Bioorg Med Chem 2009;17:7861-71.

21. O'Boyle NM, Banck M, James CA, Morley C, Vandermeersch T, Hutchison GR, et al. Open babel: An open chemical toolbox. J Cheminform 2011;3:33.

22. Adawiyah R, Suryani S, Artika IM. Histone acetyltransferase P300/ CBP-associated factor inhibition by quercetin as anticancer drug candidate with in silico and in vitro approach. Int J Pharm Pharm Sci 2016;8:211-5

23. Trott $\mathrm{O}$, Olson AJ. Autodock vina: Improving the speed and accuracy of docking with a new scoring function, efficient optimization and multithreading. J Comput Chem 2010;31:455-61.

24. Forli S. Charting a path to success in virtual screening. Molecules $2015 ; 20: 18732-58$.

25. Morris GM, Huey R, Lindstrom W, Sanner MF, Belew RK, Goodsell DS, et al. AutoDock4 and autoDockTools4: Automated docking with selective receptor flexibility. J Comput Chem 2009;30:2785-91.

26. Pratama MR, Pratomo GS. Pharmacophore optimization of berberine as HER2 inhibitor. J Pharm Indones 2017;14:109-17.

27. Du X, Li Y, Xia YL, Ai SM, Liang J, Sang P, et al. Insights into proteinligand interactions: Mechanisms, model, and methods. Int J Mol Sci 2016;17:144.

28. Meng XY, Zhang HX, Mezei M, Cui M. Molecular docking: A powerful approach for structure-based drug discovery. Curr Comput Aided Drug Des 2011;7:146-57.

29. Chen J, Almo SC, Wu Y. General principles of binding between cell surface receptors and multi-specific ligands: A computational study. PLoS Comput Biol 2017;13:e1005805.

30. Malmstrom RD, Watowich SJ. Using free energy of binding calculations to improve the accuracy of virtual screening predictions. J Chem Inf Model 2011:51:1648-55.

31. Ramirez D, Caballero J. Is it reliable to use common molecular docking methods for comparing the binding affinities of enantiomer pairs for their protein target? Int J Mol Sci 2016;17:pii E525.

32. Purwanggana A, Mumpuni E, Mulatsari E. In vitro and in silico antibacterial activity of 1.5-bis (3'-ethoxy-4'-hydroxyphenyl)-1-4pentadiene-3-one. Int J Pharm Pharm Sci 2018;10:70-6.

33. Pagadala NS, Syed K, Tuszynski J. Software for molecular docking: A review. Biophys Rev 2017:9:91-102.

34. Feng R, Qu J, Zhou W, Wei Q, Yin Z, Du Y, et al. Antibacterial activity and mechanism of berberine on avian Pasteurella multocida. Int J Clin Exp Med 2016;9:22866-92.

35. Peng L, Kang S, Yin Z, Jia R, Song X, Li L, et al. Antibacterial activity and mechanism of berberine against Streptococcus agalactiae. Int J Clin Exp Pathol 2015;8:5217-23.

36. Watt IN, Montgomery MG, Runswick MJ, Leslie AG, Walker JE. Bioenergetic cost of making an adenosine triphosphate molecule in animal mitochondria. Proc Natl Acad Sci 2010;107:16823-7.

37. Rittie L, Perbal B. Enzymes used in molecular biology: A useful guide. J Cell Commun Signal 2008:2:25-45.

38. Silhavy TJ, Kahne D, Walker S. The bacterial cell envelope. Cold Spring Harb Perspect Biol 2010;2:a000414

39. Nurhayati B, Wibowo MS, Widyastuti Y, Erawijantari PP, Widowati W, Pratama MR, et al. In silico analysis of plantaricin EF that expressed by plasmid-associated bacteriocin production gene of Lactobacillus plantarum IBL-2 for anti-candida agent potential. Res J Microbiol 2015;10:582-91. 